\title{
The Influence of Self-Efficacy on Career Maturity of High School Students in Pacitan Regency
}

\author{
Riszal Purwandika* \\ Guidance and Counseling \\ Postgraduate Program \\ Universitas Negeri Yogyakarta \\ Yogyakarta, Indonesia \\ purwandikar@gmail.com*
}

\author{
Yulia Ayriza \\ Psychology \\ Postgraduate Program \\ Universitas Negeri Yogyakarta \\ Yogyakarta, Indonesia \\ Yulia_ayriza@uny.ac.id
}

\begin{abstract}
The study aims to determine the influence of selfefficacy towards career maturity of high school students in Pacitan district. This research is an ex-post facto study with a quantitative approach. The population in this study were all public high school students in Pacitan District with a total of 3952 students. The sample size in this study was 371 students who were determined by a multi stage proportional random sampling technique. Data collection used a self-efficacy questionnaire adapted from scale to Eggen \& Kauchak selfefficacy, and career maturity questionnaire adapted from Dybwad's Career Maturity Scale. Validity is tested by content validity through expert judgment. Data were analyzed by simple regression analysis with the help of SPSS 20.0 for Windows. The results showed that self-efficacy had a positive effect on the career maturity of students.
\end{abstract}

Keywords - self-efficacy, career maturity

\section{INTRODUCTION}

Career maturity is one of the important aspects possessed by each student. Because this is related to determining the future, each student should have a clear picture of what will be the task of development and responsibility. There are still many students who have not yet gotten a picture of their chosen career that will be difficult to determine their careers. Career maturity is characterized by the maturity process that exists in the students themselves.

There are various problems experienced by students when they will determine where the career will be, and this can be seen in a variety of problems related to the study selection or when they will go directly into the world of work. Career maturity is characterized by the ability to decide what to choose.

Construction of this career maturity was introduced by [1]. Career maturity represents the place achieved in the continuum of vocational development from exploration to decline [1]. The conceptualization of career maturity is based on the assumption that career readiness is related to one's stage in vocational development [2]. In line with this opinion career maturity is defined as the level of professional knowledge in determining career choices [3]. Based on the explanation of career maturity, it can be concluded that career maturity as self-understanding and awareness in individuals to plan, prepare, take appropriate career decisions, as well as readiness for various challenges that may be encountered during each individual's life journey in accordance with his abilities.
Career maturity is basically a perception of career development experienced by each individual. Career development is certainly experiencing a difference caused by various psychological factors and circumstances in each individual. Career maturity is an important factor that must be possessed by every individual, especially students because it involves preparing themselves for the world of work [4]. In preparing the world of work, it is certainly needed as well as mental readiness, behavior, and also other supporting knowledge. This agrees with Betz's statement defines career maturity as the extent to which individuals have mastered vocational tasks, including knowledge and attitude components, according to the stage of career development [5].

Career maturity is readiness to make appropriate career decisions. From these various statements, career maturity is a component of the attitude that exists in the individual to prepare a situation about the individual in order to carry out development tasks related to the career development task that will be passed by each individual.

Researchers have also conducted interviews with several students in 1 Punung Public High School in the week two in July 2018. Students interviewed by researchers numbered 10 people, including 5 of these students experiencing difficulties in career maturity. Due to several factors including a lack of understanding of the strengths and weaknesses of each student, there is still an attitude from parents who must obey later to have a career or choose a department in a predetermined place, just follow their friends so they can still gather, lack of self-confidence in making choices related to his career, lack of motivation and supporting factors to strengthen his career choices.

Low career maturity of students can cause losses in determining success in the future. Especially if students do not understand the obstacles that will come from within themselves and from outside of the students themselves. Internal obstacles are more often found such as problems with the psychological and family environment that are less supportive. Mubiana argues, the appropriate stage of readiness in shaping career maturity means that the person must have the right cognitive abilities to be handled in a variety of career challenges that may arise in the course of their lifetime [6]. So that it can be stated that career maturity is a construction that is useful for measuring the level of career development in students. 
The main components of a career consist of career path, career goals, career planning and career development [7]. Career path is a sequential work pattern that shapes a person's career. Career goals are views about the position or position to be achieved by someone in the future. Career planning is the process of a person carrying out the selection of career goals and career flows to achieve his career goals. Career development consists of personal improvements made to achieve his career goals and plans. Research conducted by Jawarneh, to improve the level of career maturity in a sample of students at a state university in Jordan, yields findings of the importance of increasing understanding of self-knowledge, knowledge of the world of work, and career planning to provide several recommendations relating to preparing students for the work environment [8].

Based on the opinion above, it can be concluded that career maturity is influenced by several internal and external factors. Where these factors affect the career maturity of each student in achieving his future career. And family factor is considered to be the most important factor in the career maturity of each individual, because the development period, childhood experience, and the role of parents contribute to the growth and development of children, so it will affect the development of children especially in terms of career maturity in the future.

Students who are ready with the career maturity they have, will always be sure of the obstacles that will be passed later. Confidence in oneself also plays an important role in strengthening established behavior. Such behavior is a picture that is on students in stabilizing the objectives to be chosen. Students who have already planted their confidence well, the obstacles that affect them will be passed with full confidence that he can. And this will strengthen the career maturity that began to be determined. Self-confidence is actually related to the stability that is embedded in each individual. Bandura also explains that self-efficacy is a belief held in a person with his ability to achieve a certain goal [9].

Self-efficacy is actually related to the stability that is embedded in each individual regarding a task he is doing. This becomes a complex problem when individuals are not ready and their career maturity is not conceptualized. And of course it will also have an impact on the future of the students themselves. In terms of career maturity, selfefficacy certainly becomes a driving force in self so that students will strengthen their chosen career fields. Schunk also argues, self-efficacy is a belief that every individual has to be able to do something well [10]. And it is also in line with the results of research conducted by Singh \& Shukda in 2015 which obtained the results that, self-efficacy is positively correlated to career maturity in high-level students [11].

It can be concluded that, self-efficacy can bring each individual to be better and more meaningful in linking a task and purpose in a life phase. Conversely, if self-efficacy in individuals is low, it will have a negative impact on a task and purpose to be lived in the future. Specifically, low selfefficacy can lead to distrust and despair about one's ability to respect oneself [12].
Gregory defines that self-efficacy as self-confidence to know its capabilities so that it can carry out a form of control of the benefits of the person himself and events in the surrounding environment [13]. Self-efficacy also connects humans with the motivation they have, the process of thinking, and acting in believing what they want [14]. In line with this, Cera, Mancini, \& Antonietti also state that self-efficacy is a belief in individuals with abilities possessed in increasing expectations, motivation, cognitive power, and carrying out an action needed to carry out tasks [15].

From some of these theories it can be concluded that self-efficacy is a form of self-efficacy that arises with awareness and brings hope to the individual self to do the desired thing. Self-efficacy is also a benchmark to measure the ability possessed by each individual.

The results of related studies conducted by Gaylor \& Nicol in 2016 revealed the existence of positive findings when students were asked to complete career decisions by inculcating self-efficacy adjusted [16]. This is very helpful for students when teachers in schools are also active in making students feel confident about career maturity later. So, it can be concluded that self-efficacy is a belief about itself in dealing with situations and how confident students are to reach the goals they will achieve.

Self-efficacy has a big role in behavior, especially in determining career selection, because it can determine the future of participants in the class. High self-efficacy certainly has an impact on the solidity of students in career maturity, and is able to complete tasks and problems faced with confidence. On the contrary, participants who had selfefficacy low felt reluctant to determine the future. The relevant research results conducted by Tarigan \& Wimbarti in 2011, revealed that there were positive findings regarding career planning programs that were very effective in increasing self-confidence in career searches for 39 new undergraduate graduates who had been divided into control groups not treated with experimental design pre-tests and post-tests that have been carried out in the study [17].

This is very helpful for students when the teacher in the school is also actively encouraging his confidence in career maturity that will help him achieve his goals. From these results it can be concluded that self-efficacy has a positive role to support each individual self in achieving the dream that will be lived.

Developmental factors in self-efficacy are also based on social cognitive theories that have been developed previously. The factors that influence the development of self-efficacy, including the success and failure of a person before, the current emotional state, the message communicated by others, the successes and failures of others, and the successes and failures of one's group as a whole [18].

Eggen \& Kauchak classifies four factors that influence self-efficacy beliefs, namely: 1) past performance; related to the performance of the individual with the tasks that have been completed, and that will have an impact on his beliefs with the task that will be faced next, 2) modeling; in connection with the results of the performance of others who are good become a reference and self-encouragement to be 
able to make the results of his work even better, 3) verbal persuasion; words of encouragement or praise given to someone who has done a good job, and this will trigger high self-confidence that he can do the job well, 4) psychological state; a physiological picture such as anxiety, fatigue or hunger, which will affect one's own performance [19].

From the explanation above, it can be concluded that there are several factors that influence self-efficacy. Indeed these factors can make an option to continue to be in selfconfidence that in each individual must experience a success about something that has been chosen and believed.

Students who have self-efficacy strong in themselves can encourage the level of career maturity dreamed about in relation to their ideals. And high self-efficacy can convince students to always be sure of the choices that will be pursued related to later careers. From the explanation above, the researcher is interested in knowing the effect of self-efficacy on career maturity in high school students in Pacitan Regency.

\section{METHODS}

Type of research used in this study is ex-post facto.It is known that the total population of public high school students in Pacitan Regency is 3,952 students. The sample size taken in this study uses a reference from the sampling technique in the Krejcie \& Morgan table using a multi stage proportional random sampling technique. The stage first distinguishes the school based on its class, namely each school is taken class X, class XI, and class XII. The stage second selects schools randomly in proportion to the number of students per class of approximately 30 students. The selected schools were Senior High School 1 Punung, Senior High School 2 Pacitan, Senior High School 1 Pacitan, and Senior High School 1 Ngadirojo. Which then obtained a sample of 371 students.

Data collection in this study was conducted using the scale of adaptation, namely, the scale of self-efficacy that has been described based on the scale to be the characteristic of self-efficacy of [19]. These characteristics consist of task orientation, effort, persistence, confidence, use of strategy, and performance. The total items consist of 13 items that have been adjusted based on the needs of students in high school. The reliability results on the scale self-efficacy are 0.615. And, scale adaptation from Dybwad which has been compiled based on finished scale in the form of attitudes, support, career confidence, uncertainty of career choice, and career knowledge [20]. Total items consist of 12 statement items that have been adapted to the needs of high school students. The reliability results on the scale of career maturity are 0.736 .

The validity technique uses content validity which is then carried out through testing expert judgment. So after testing expert judgment, the researcher selects items by using the total item correlation coefficient technique $\left(\mathrm{r}_{\mathrm{ix}}\right)$ which is commonly called a different item power index with a criteria limit of 0.30 . The different power tests are carried out by calculating the total item score correlation coefficient $\left(r_{i x}\right)$, which then results in a minimum score of 0.360 so that the item is feasible [21].
The reliability test in this study used the Cronbach's Alpha method, with the decision-making method using the limit of 0.60 . If the value is cronbach alpha $>0.60$ then it is reliable, conversely if the value is cronbach alpha $<0.60$ then it is declared unreliable. The data analysis technique used in this study is a simple regression analysis. To simplify the statistical calculation process, the overall calculation in this study uses the SPSS 20.0 for Windows program.

\section{III.RESULT AND DISCUSSION}

Result

Descriptive statistics provide a description of the data in this study that applies to each research variable.

Table 1. Results of Frequency Distributionvariables SelfEfficacy

\begin{tabular}{|c|c|c|c|}
\hline Interval & Category & Frequency & $\begin{array}{c}\text { Percentag } \\
\text { e }\end{array}$ \\
\hline $\mathrm{X} \leq 30$ & Very Low & 23 & $6 \%$ \\
\hline $30<\mathrm{X} \leq 34$ & Low & 123 & $33 \%$ \\
\hline $34<\mathrm{X} \leq 38$ & Enough & 160 & $43 \%$ \\
\hline $38<\mathrm{X} \leq 42$ & High & 43 & $12 \%$ \\
\hline $\mathrm{X}>42$ & Very High & 22 & $6 \%$ \\
\hline \multicolumn{2}{|c|}{ Total } & 371 & $100 \%$ \\
\hline
\end{tabular}

From table 1, it can be seen that the majority of selfefficacyschool of highstudents in Pacitan Regency is in a sufficient percentage with $43 \%$.

Table 2. Results of Frequency Distribution Variables Maturity Career

\begin{tabular}{|c|c|c|c|}
\hline Interval & Kategori & Frekuensi & Presentase \\
\hline $\mathrm{X} \leq 26$ & Very Low & 62 & $17 \%$ \\
\hline $26<\mathrm{X} \leq 30$ & Low & 148 & $40 \%$ \\
\hline $30<\mathrm{X} \leq 34$ & Enough & 114 & $31 \%$ \\
\hline $34<\mathrm{X} \leq 38$ & High & 33 & $9 \%$ \\
\hline $\mathrm{X}>38$ & Very High & 14 & $4 \%$ \\
\hline \multicolumn{2}{|c|}{ Total } & 371 & $100 \%$ \\
\hline
\end{tabular}

From table 2, it can be seen that the majority of the career maturity of high school students in Pacitan Regency is at a low percentage with $40 \%$.

To prove the truth of the hypothesis, the data to be analyzed requires several test requirements. The prior to the regression analysis it is necessary to test the classical assumptions first [22]. For this analysis prerequisite test includes multicollinearity test the results obtained Tolerance value of the variable self-efficacy of $1.000>$ from 0.10 and the VIF value of $1.000<$ from 10.00 , it can be concluded that the data on these variables do not occur multicollinearity, and linearity test obtained the significance value of devitiation from linearity $=0.110>$ of 0.05 , which means there is a significant linear relationship between the variables of self-efficacy on students career maturity variable. Below this table presents the results of multicolinearity and linerity.

Tabel 3. Summary of Multicolinearity Test

\begin{tabular}{|l|c|c|}
\hline \multirow{2}{*}{ Model } & \multicolumn{2}{|c|}{ Collinearity Statistics } \\
\cline { 2 - 3 } & Tolerance & VIF \\
\hline 1 (Constant) & & \\
\hline Self-Efficacy & 1.000 & 1.000 \\
\hline
\end{tabular}

Based on the results from table 3, shows the Tolerance value of the self-efficacy variable is $1.000>$ from 0.10 and 
the VIF value is $1.000<$ from 10.00 , it can be concluded that the data on the variable does not occur multicollinearity.

Table 4. Summary of The Results of The Linearity of Self Efficacy to Career Maturity

\begin{tabular}{|ccc|c|}
\hline & & & Sig \\
\hline $\begin{array}{c}\text { Career } \\
\text { Efficacy }\end{array}$ & Maturty & $*$ & Self- \\
\hline
\end{tabular}

Based on the significance value from table 4 , obtained a significance value of Devitiation from Linerity $=0.110>$ from 0.05 , which means that there is a significant linear relationship between the variables of self-efficacy to the variables of student career maturity.

Hypothesisproposed in this study is:

Ho $=$ There is no significant effect of self-efficacy on student career maturity.

$\mathrm{Ha}=$ There is a significant effect between self-efficacy on student career maturity.

Table 5. Result of Hypothesis

\begin{tabular}{|l|c|c|c|c|c|}
\hline \multicolumn{3}{|c|}{$\begin{array}{c}\text { Unstandardized } \\
\text { Coefficients }\end{array}$} & \multicolumn{3}{c|}{ Standardized Coefficients } \\
\hline Model & B & $\begin{array}{c}\text { Std. } \\
\text { Error }\end{array}$ & Beta & t & Sig. \\
\hline (Constant) & $\begin{array}{c}14.41 \\
4\end{array}$ & 1.873 & & 7.694 & 0.000 \\
\hline $\begin{array}{l}\text { Self- } \\
\text { Efficacy }\end{array}$ & .495 & 0.52 & .443 & 9.487 & 0.000 \\
\hline
\end{tabular}

Based on table 5, the results of the hypothesis test can be explained, namely, the results of t count 9.487 and the significance value of $0.000<0.05(\mathrm{p}<0.05)$ which means that $\mathrm{Ho}$ is rejected and $\mathrm{Ha}$ is accepted, namely the selfefficacy variable has a significant effect on the variable career maturity. This means that self-efficacy can predict the career maturity of students. To see the regression line in table 5 , it can be seen by looking at the beta value, it can be formed a regression line equation, namely $Y^{\prime}=a+b X$. If $a$ $=$ constant (14.414) and $\mathrm{b}=$ coefficient $\mathrm{X}(0.443)$, the regression line equation is obtained, if $\mathrm{X}$ is increased by one unit then $\mathrm{Y}=14.414+0.443 \times 1$. And if $\mathrm{X}$ is increased to two units then $\mathrm{Y}=14.414+0.443 \times 2$. This means that if seen in a simple way, self-efficacy can predict career maturity in students.

Table 6. Summary of The Contribution Test Result Effect X on Y

\begin{tabular}{|c|c|c|c|c|}
\hline Model & $\mathbf{R}$ & R Square & $\begin{array}{c}\text { Adjusted R } \\
\text { Square }\end{array}$ & $\begin{array}{c}\text { Std. Error of } \\
\text { the Estimate }\end{array}$ \\
\hline 1 & $443^{\mathrm{a}}$ & .196 & .194 & 3.973 \\
\hline
\end{tabular}

Based on table 6 above, the Adjusted R Square value can be seen at 0.194 . so it can be said, the contribution of the influence of the independent variable self-efficacy to the dependent variable of student career maturity in this study amounted to $19.40 \%$, while the remaining $80.60 \%$ was influenced by other factors. The distribution of the amount of contribution is presented in the form of a pie chart model as illustrated below:

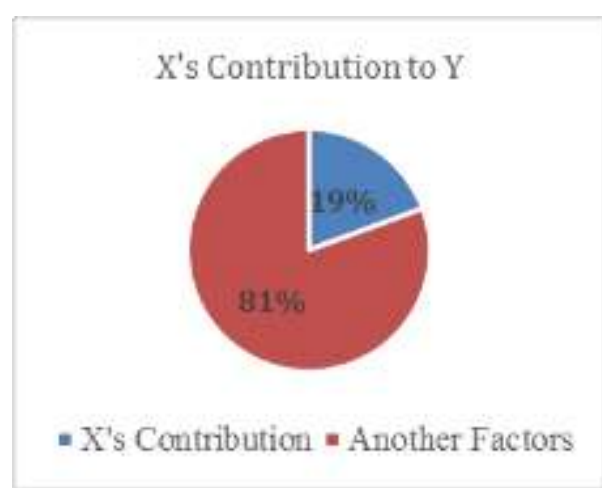

Figure 1. The amount of contribution of influence of variable $\mathrm{X}$ on $\mathrm{Y}$

\section{Discussion}

In terms of age and stage of career development, in general high school students are classified as middle-aged adolescents. In this middle adolescence, high school students in their cognitive development will continue to increase, have begun to be able to set and choose a goal, and are interested in things that are more rational and start thinking about the meaning of life. Developments in middle adolescence also have an impact in terms of career maturity in students.

Students who have high self-confidence will be able to adjust and prepare for career maturity related to careers for future goals. This study aims to determine the magnitude of the effect of self-efficacy on career maturity of high school students in Pacitan District. The results showed that selfefficacy can predict career maturity. Relevant research conducted by Cardoso \& Moreira in 2009 in 583 adolescents in a public school in Portugal with male and female participants in the age range 13-23 years found findings that self-efficacy in career selection plays a positive role with career planning that they will specify [23]. The choice of career is also part of the career maturity students will pass later.

It can also be explained in this study that someone who has positive self-confidence will also have an effect on the career maturity to be addressed. In this case career maturity is related to job selection and further study.

Other relevant research, examined the Career decision making of Greek student post secondary vocational: the impact of parents and career decision making self-efficacy [24]. The purpose of the study was to determine the influence of parents in making career decisions after graduating in high school. The study was survey research using a questionnaire with a total of 148 student respondents. The results showed that there was a significant correlation between student career self-efficacy and career decision making. Furthermore the results of the study also showed a strong correlation between the influence of parents and career decision-making abilities. Agreeing with the results of the study, Cervone \& Pervin also stated that people with low self-efficacy would be potentially threatened with high anxiety and anxiety, including being threatened in their future careers [25].

From the two results of the study it can be concluded that self-efficacy has a positive effect on career maturity that will 
be achieved by each individual. The higher the self-efficacy of the individual, the greater the chance of success in terms of the career maturity of his dreams, and vice versa if the individual has low self-efficacy will potentially disrupt the process of maturity in the career maturity.

The equation of this research with previous research is together to discuss the factors of career maturity and selfconfidence. And in this study, researchers want to see the influence of independent variables on dependent variables without taking action to change the cause and effect of each variable under study. Because basically ex-post facto is a phenomenon or event that has taken place, the researcher wants to look back at the self-confidence factor in career maturity in the students of Public High School in Pacitan Regency. It can be concluded if students who have positive self-confidence, career maturity in students will show readiness in determining future careers.

\section{IV.CONCLUSION}

Based on the results of research and discussion that has been stated, it can be explained that in order to improve career maturity an intervention is carried out on the variable self-efficacy. For further researchers, this research can be used as a reference and reference material in the personal and career fields in the future.

\section{REFERENCES}

[1] Super, D. E. (1957). The psychology of careers. New York: Harper \& Row.

[2] Mabel, S. B \& Nagarenitha, M. (2016). Career maturity and career decision-making: A Review. International Education and Research Journal. Vol 2, No.12. Retreived from http://ierj.in/journal/index.php/ierj/article/view/593.

[3] Supreet, K \& Mamta, J. (2018). Career maturity of students with visual impairment in relation to their self efficacy and self advocacy. Journal of Social Sciences. Vol. 14: 30.42. Retreived from http://thescipub.com/pdf/10.3844/jssp.2018.30.42.

[4] Tekke, M., \& Ghani, M.F.A. (2013). Examining The Level of Career Maturity Among Asian Foreign Students in a Public University: Gender And Academic Achievement. Hope Journal of Research. House of Pakistani Educationists. Vol. 1, No. 1.

[5] Whiston S.C. (2013). Principles and applications of assesment in counseling (4th ed). USA: Brooks/Cole.

[6] Mubiana, P.B. (2010). Career maturity, career knowledge, and self knowledge among psychology honours students: An exploratory study.
Dissertation Department of Psychology University of Pretoria Faculty of Humanities.

[7] Mangkuprawira, S. (2011). Strategic human resource management. Bogor: Ghalia Indonesia.

[8] Jawarneh, Mohammad. (2016). Career Maturity Among University Students in Jordan: The Case for Social Studies. Australian Journal of Career Development. No.3, Vol.25.Retreived from http://journals.sagepub.com/doi/abs/10.1177/1038416216676807.

[9] Bandura, A. (2012). On the functional properties of perceived selfefficacy revisited. Journal of Management, 38, 9-44.

[10] Schunk, D.H. (2012). Learning theorities an educational perspective (6th). Boston: Pearson Education, Inc.

[11] Singh, P.K., \& Shukda, R.P. (2015). Relationship Between Career Maturity and Self-Efficacy Among Male and Female Senior Secondary Students. MIER Journal of Educational Studies, Trends \& Practices. Vol. 5, No. 2. 164-179.

[12] Al Khatib, S.A. (2014). Exploring the Relationship among Lonelines, Self-esteem, Self-efficacy, and Gender in United Arab Emirates College Students. Europe's Journal of Psychology, 8(1), pp. 159-181.

[13] Gregory, J. F. (2011). Personality theory. Jakarta: Salemba Humanika.

[14] McCoach, D., Gable, R., \& Madura, J. (2013). Instrument development in the affective domain. New York, NY: Springer.

[15]Cera, R., Mancini, M., \& Antonitti, A. (2013). Relationships between metacognition, self-efficacy and self-regulation in learning. ECPS Journal, 7, 115-141.

[16]Gaylor, Lisa \& Nicol, J.L. (2016). Experiental high school career education, self-Efficacy, and motivation. Canadian Journal of Education. 39:2.

[17] Tarigan, M \& Wimbarti, S. (2011). Career planning program to increase career search self efficacy in fresh graduates. Journal of Higher Education Theory and Practice vol. 11(4).

[18] Ormrod, J E. (2008). Educational psychology. (Jakarta : Erlangga.

[19]Eggen, Paul \& Kauchak, D. (2010). Educational psychology: Windows on classrooms. 8th ed. Pearson Education Inc.

[20] Dybwad, T. E. (2008). The structural validity of daidalos: A measure of career maturity. Scandinavian Journal of Educational Research. $135: 152$.

[21] Azwar, Saifuddin. (2017). Compilation of the psychological scale (edition 2). Yogyakarta: Student Library.

[22] Ghozali, I. (2011). Multivariate analysis application with IBM SPSS 19. Edition 5. Semarang: Diponegoro University.

[23]Cardoso, P \& Moreira J.M. (2009). Self-efficacy beliefs and the relation between career planning and perception of barriers. Int J Educ Vocat Guidance (2009) 9:177-188. Retreived from doi 10.1007/s10775-009-9163-2.

[24] Kounenou, K. (2011). Career decision making of Greek post secondary vocational students: the impact of parents and career decision making self-efficacy. N. Heraklion, Attiki, Greece, School of Pedagogical and Technological Educatioan. 141, 3410-3414.

[25] Cervone, Daniel \& Parvin, Lawrence A. (2012). Kepribadian: Research and theory $\left(10^{\text {th }}\right.$ edition). (Translation: Aliya Tusyani). Jakarta: Salemba Humanika. 